\title{
Paleolimnological assessment of nutrient enrichment on diatom assemblages in a priori defined nitrogen- and phosphorus-limited lakes downwind of the Athabasca Oil Sands, Canada
}

\author{
Kathleen R. LAIRD,${ }^{1 *}$ Biplob DAS, ${ }^{2}$ Brittany HESJEDAL, ${ }^{3}$ Peter R. LEAVITT, ${ }^{3,4}$ Graham R. MUSHET, ${ }^{1}$ \\ Kenneth A. SCOTT, ${ }^{5}$ Gavin L. SIMPSON, ${ }^{4}$ Björn WISSEL, ${ }^{4}$ Jared WOLFE, ${ }^{3,4}$ Brian F. CUMMING ${ }^{1}$
}

${ }^{1}$ Paleoecological Environmental Assessment and Research Laboratory, Dept. of Biology, Queen's University, 116 Barrie Street, Kingston, ON, Canada, K7L 3J9; ${ }^{2}$ Saskatchewan Water Security Agency, 420-2365 Albert Street, Regina, SK, Canada, S4P 4K1; ${ }^{3}$ Department of Biology, University of Regina, 3737 Wascana Parkway, Regina, SK, Canada, S4S 0A2; Institute of Environmental Change \& Society, Dept. of Biology, University of Regina, 3737 Wascana Parkway, Regina, SK, Canada, S4S 0A2; ${ }^{5}$ Saskatchewan Ministry of Environment, 3211 Albert Street, Regina, SK, Canada, S4S 5W6

*Corresponding author: lairdk@queensu.ca

\begin{abstract}
As the industrial footprint of the Athabasca Oil Sands Region (AOSR) continues to expand, concern about the potential impacts of pollutants on the surrounding terrestrial and aquatic ecosystems need to be assessed. An emerging issue is whether recent increases in lake production downwind of the development can be linked to AOSR activities, and/or whether changing climatic conditions are influencing lake nutrient status. To decipher the importance of pollutants, particularly atmospheric deposition of reactive nitrogen $(\mathrm{Nr})$, and the effects of climate change as potential sources of increasing lake production, lakes from both within and outside of the nitrogen deposition zone were analyzed for historical changes in diatom assemblages. Lake sediment cores were collected from a priori defined nitrogen (N) - and phosphorus (P) - limited lakes within and outside the N plume associated with the AOSR. Diatom assemblages were quantified at sub-decadal resolution since ca. 1890 to compare conditions prior to oil sands expansion and regional climate warming, to the more recent conditions in each group of lakes (Reference and Impacted, N- and P-limited lakes). Analyses of changes in assemblage similarity and species turnover indicates that changes in diatom assemblages were minimal both within and across all lake groups. Small changes in percent composition of planktonic taxa, particularly small centric taxa (Discostella and Cyclotella species) and pennate taxa, such as Asterionella formosa and Fragilaria crotonensis, occurred in some of the lakes. While these changes were consistent with potential climate effects on algal growth, water column stability and other factors; the timing and direction of biotic changes were variable among sites suggesting that any apparent response to climate was lake dependent. The absence of a consistent pattern of diatom changes associated with receipt of reactive nitrogen or intrinsic nutrient-limitation status of the lake suggest that downwind AOSR emissions had no demonstrable effect on diatom composition.
\end{abstract}

Key words: Athabasca oil sands; nitrogen deposition; diatom assemblages; nutrient limitation.

Received: November 2016. Accepted: February 2017.

\section{INTRODUCTION}

The Athabasca Oilsands Region (AOSR) has the largest bitumen reserves in the world (Lynam et al., 2015), with development starting in 1967, intensifying during the 1980s, and achieving near exponential growth beginning in the 1990s (Schindler, 2010, 2013). As the industrial footprint in the AOSR expanded, emissions of carbon dioxide, sulphur oxides, nitrogen oxides and other pollutants increased (Aherne and Shaw, 2010; Kelly et al., 2010; Kurek et al., 2013), leading to concerns about the impacts of the AOSR industrial activities on the surrounding terrestrial and aquatic ecosystems (Schindler, 2013).
Initial environmental focus was on the impacts of sulphur and nitrogen compounds as acidifying agents leading to lake acidification, as seen in eastern North America (Sullivan et al., 1990; Cumming et al., 1994).

To date, the analysis of fossil diatom assemblages to infer past lake-water $\mathrm{pH}$ trends (Smol et al., 1986) from boreal lakes in Alberta close to the AOSR, as well as further downwind in Saskatchewan, showed limited evidence of regional surface-water acidification (Hazewinkel et al., 2008; Curtis et al., 2010; Laird et al., 2013). Although, upland forest soils in the AOSR should be sensitive to acid deposition, due to their extremely low base cation weathering rates, previous studies indicate that the 
risk of acidification is largely mitigated by the high deposition of base cations, even within $20 \mathrm{~km}$ of the industrial center where acid deposition is very high (Watmough et al., 2014; Fenn et al., 2015). Instead, environmental concerns now focus on the potential eutrophication impacts resulting from deposition of reactive nitrogen, $\mathrm{Nr}$ (Fenn et al., 2015). Evidence from the sedimentary studies of lakes in close proximity to the AOSR indicated elevated abundance of diatom species typical of higher nutrient conditions in a number of the lakes (Hazewinkel et al., 2008; Curtis et al., 2010), as well as increased rates of diatom production from cores in basins downwind in Saskatchewan (Laird et al., 2013). Together these studies speculate that enhanced production may result from a complex interaction between climate change, internal nutrient loading, and deposition of nitrogen $(\mathrm{N})$ compounds derived from the AOSR.

Anthropogenic deposition of $\mathrm{N}$ from agriculture and fossil fuel combustion has been linked to nutrient enrichment of lakes, particularly oligotrophic lakes in high-altitude and high-latitude regions (Elser et al., 2009a; Baron et al., 2011; Lepori and Keck, 2012). Other studies have also implicated a potential synergy between climate warming and nutrient stimulation of $\mathrm{Nr}$ deposition (Thompson et al., 2008; Bergström et al., 2013; Spaulding et al., 2015). The importance of the deposition of inorganic $\mathrm{N}$ (nitrate and ammonium) on aquatic ecosystems is dependent on many factors, including soil cover and vegetation composition which influence soil $\mathrm{N}$ content, microbial $\mathrm{N}_{2}$ fixation and export to lakes (Baron et al., 2011; Lepori and Keck, 2012). In particular, lakes with limited catchment vegetation may receive a higher proportion of deposited $\mathrm{N}$ and may respond more quickly to enrichment than water-bodies in forested catchments (Fenn et al., 2003; Baron et al., 2011). Low levels of $\mathrm{N}$ deposition have led to pronounced ecological changes in some oligotrophic alpine lakes in the U.S. Colorado Front Range of the Rocky Mountains, as revealed through both limnological (Elser et al., 2009b) and paleolimnological studies (Wolfe et al., 2001; Saros et al., 2005b). Despite potentially important effects, the role of AOSR-derived N as a nutrient stimulus on lakes in the boreal region of northwest Saskatchewan is not known.

Fertilization effects of $\mathrm{Nr}$ should be greatest in lakes where growth of phytoplankton is limited by the supply of $\mathrm{N}$. Although there is a continuing debate on the relative role of $\mathrm{N}$ and $\mathrm{P}$ as controls of lake production and eutrophication (Lewis and Wurtsbaugh, 2008; Schindler, 2012; Schindler et al., 2016), many studies show that $\mathrm{N}$ can limit phytoplankton growth alone or in conjunction with supply of P (Elser et al., 1990; Downing and McCauley, 1992; Guildford and Hecky, 2000; Nydick et al., 2004; Bergström and Jansson, 2006; Lewis and Wurtsbaugh, 2008). A long-term study of Mirror Lake, New Hamp- shire, U.S. indicates it has remained nutrient poor for over 30 years and co-limited by $\mathrm{N}$ and $\mathrm{P}$ (Winter and Likens, 2009). A large survey of lakes in the U.S. estimated that $\sim 18 \%$ were nitrogen limited and another $\sim 19 \%$ were colimited by $\mathrm{N}$ and $\mathrm{P}$ (Baron et al., 2011), although nutrient limitation status may also vary among seasons (Morris and Lewis, 1988; Kolzau et al., 2014).

To address the potential importance of $\mathrm{N}$ deposition on the production of lakes downwind from the AOSR, we selected lakes in a priori defined groups of $\mathrm{N}$-limited and $\mathrm{P}$-limited lakes in regions known to receive enhanced Ndeposition from the AOSR (Environment Canada's IMP, 2011a). Historical changes in fossil diatom assemblages in these sites were compared to those from reference Nlimited and P-limited lakes located outside of the potential AOSR-impacted zone to isolate the effects of $\mathrm{Nr}$ deposition from those of regional climate change. This study analyzed fossil diatom assemblages in sediment cores to evaluate whether historical changes in these primary producers could be related to nutrient enrichment or climate influences since $\sim 1890$ CE.

\section{METHODS}

\section{Lake selection and study sites}

Study basins were selected from a dataset of 262 lakes sampled during September-October in 2007-2009 and 2011 by the Saskatchewan Ministry of Environment within $\sim 300 \mathrm{~km}$ of Fort McMurray, and represent an expansion of the survey provided by Scott et al. (2010). Individual lakes were sampled in 1 to 4 years. Initial site selection was based on choosing sites with small to moderate lake size, $\sim 9-250$ ha ( $\sim 76 \%$ of lakes); depth, $\sim 4-29$ $\mathrm{m}(\sim 51 \%$ of lakes); and catchment area: lake surface area of $\sim 3-50$ ( $\sim 83 \%$ of lakes). Secondary selection removed lakes with outlier chemistry (high dissolved organic carbon, DOC; total nitrogen, TN or total phosphorus, TP; alkalinity and specific conductivity), while lakes with $<6$ $\mathrm{mg} \mathrm{L}^{-1}$ alkalinity were removed to reduce potential sensitivity to acidification (Laird et al., 2013). Study sites were located either within a zone modelled by Environment Canada (2011a, Fig. 3.4, p. 50) to receive AOSR emissions, $<\sim 150 \mathrm{~km}$ from AOSR (termed potential impact lakes) or a reference region outside the modelled deposition zone, $>\sim 200 \mathrm{~km}$ from AOSR (Fig. 1). Of the 43 lakes remaining after initial screening, basins were then identified as potentially $\mathrm{N}$ - or P-limited based on molar dissolved inorganic nitrogen to total phosphorus (DIN:TP) ratios: $<3.5$ DIN:TP (N-limited or $\mathrm{N}+\mathrm{P}$ colimited; Bergström, 2010); and $>7$ (majority $>10$ ) DIN:TP (P-limited) in both impacted and reference regions. Morris and Lewis (1988) indicated from bioassay experiments that the most accurate index of limitation (out of 9 indices, 
including TN:TP) was based on DIN:TP, as bioavailable nitrogen is better approximated by DIN (ammonium and nitrate). Bergström (2010) and Kolzau et al. (2014) also found DIN:TP ratios to be the best predictor of nutrient limitation. The resulting suite of lakes were then divided into a $2 \times 2$ factorial design, with at least 4 lakes in each group: four reference $\mathrm{N}$ - or $\mathrm{N}+\mathrm{P}$-limited lakes (hereafter Ref N-limited), four Ref P-limited lakes, four impact Nor N+P-limited lakes (henceforth Imp N-limited) and four Imp P-limited lakes. Lakes that were only sampled once, or had high variance in the multiple estimates of DIN:TP were not included in the final suite of lakes, except in the case of the impact $\mathrm{N}$-limited lakes, as preliminary screening greatly reduced the number of available lakes in this category.

A non-metric multidimensional scaling (nMDS) ordination of the physical (area, depth) and chemical characteristics (chlorophyll $a$, Chl $a$; ammonium, $\mathrm{NH}_{4}-\mathrm{N}, \mathrm{TN}$, $\mathrm{TP}$, DOC, dissolved inorganic carbon, DIC; chloride, $\mathrm{Cl}$; sulfate, $\mathrm{SO}_{4}$, silica, $\mathrm{Si}$; alkalinity and $\mathrm{pH}$ ) was used to identify outlier lakes (those furthest from ordination centroid), resulting in the selection of a total of 22 candidate lakes with similar characteristics in each of four groups (Tab. 1 and Supplementary Tab. 1). Study and alternate lakes (selected in case of poor chronological control) included: four Ref N-limited lakes, four Ref P-limited lakes, five Imp N-limited lakes ( + two alternatives) and five 5 Imp P-limited lakes (+ two alternatives). Due to poor weather conditions and travel restrictions, one of our northern Ref P-limited sites and the two alternate Imp Plimited sites were not sampled.

Regional climate of the study region is characterized as Subarctic, with mean annual temperature at $\sim 2.3^{\circ} \mathrm{C}$, mean annual precipitation from $\sim 450$ to $530 \mathrm{~mm}$, with $300-320$ $\mathrm{mm}$ of rain occurring between May and September (Scott et al., 2010). Vegetation in the region consists primarily of jack pine (Pinus banksiana)/ lichen forest with balsam fir (Abies balsamea) and trembling aspen (Populus tremu-

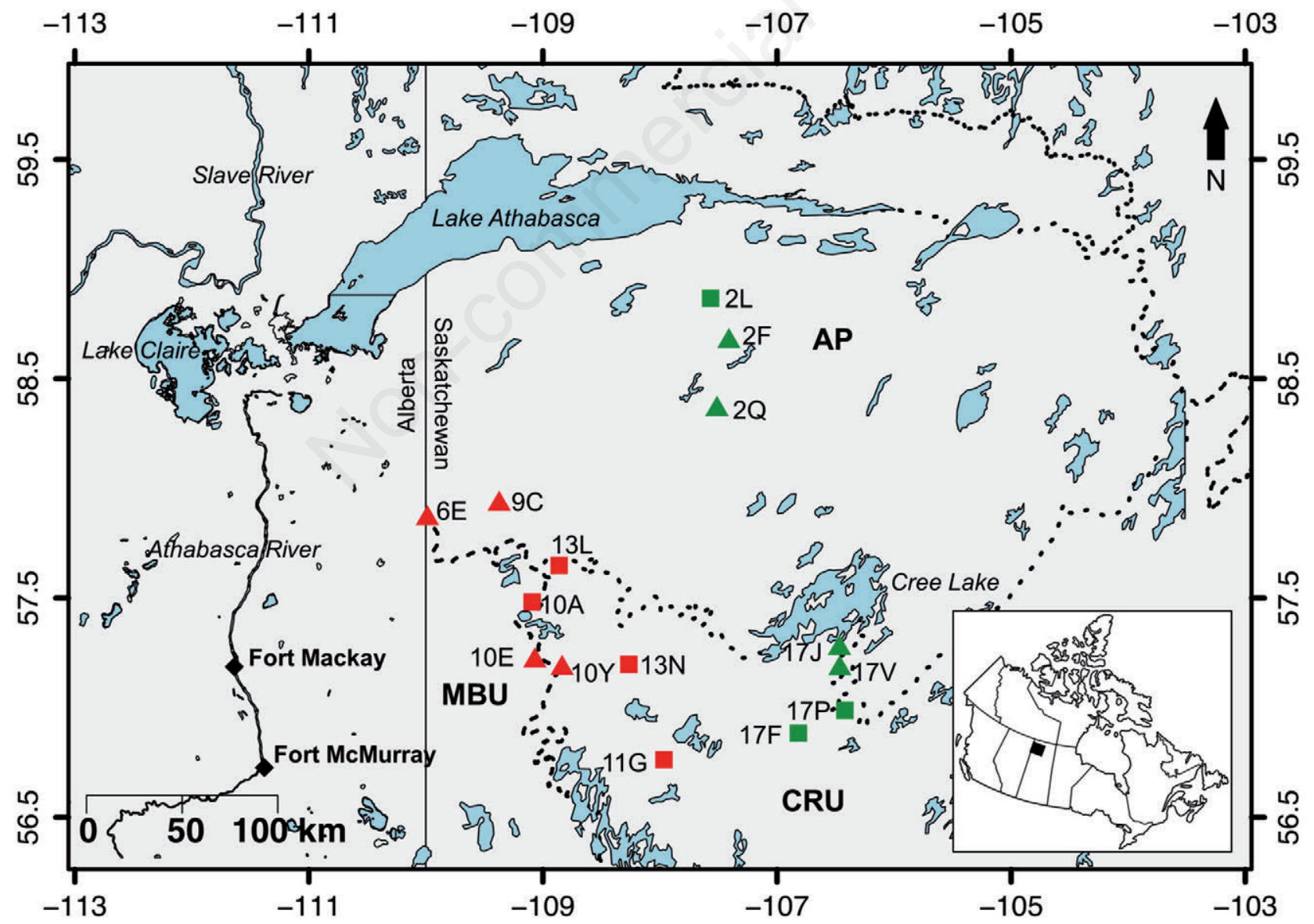

Fig. 1. Location of the 15 study lakes in northwest Saskatchewan: impact N-limited lakes are red triangles; impact P-limited lakes are red squares; reference N-limited lakes are green triangles; reference P-limited lakes are green squares. Ecoregions Athabasca Plains (AP), Churchill River Upland (CRU) and Mid-Boreal Upland (MBU) are identified. 


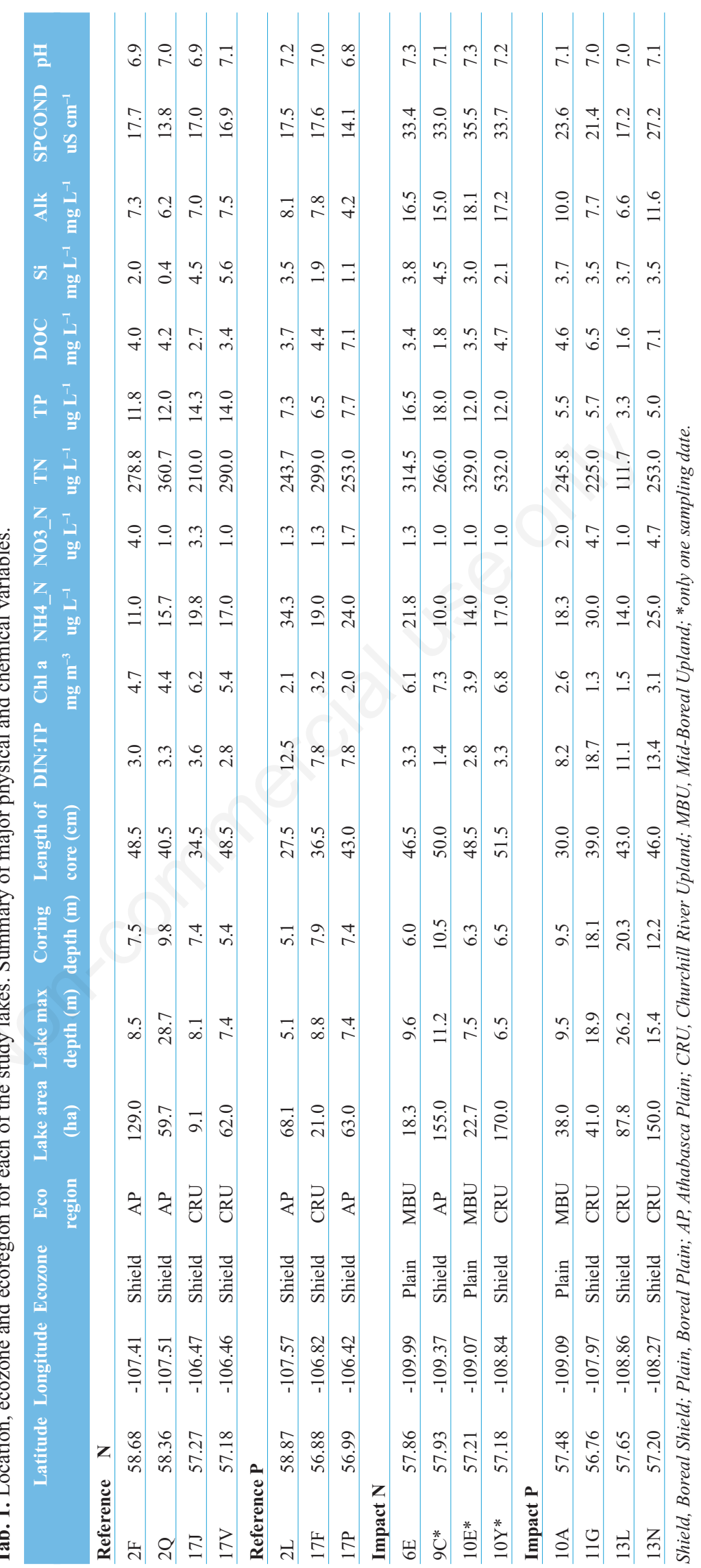


loides) in areas with well-drained mineral soils; in the more poorly drained regions black spruce (Picea mariana) dominates. Further details of the ecoregions, geology and vegetation can be found in Scott et al. (2010).

\section{Sediment coring and sampling}

Collection of cores took place in February (11 lakes) and April (8 lakes) of 2014 (Fig. 1). Sites were accessed via a helicopter and cored from the ice using a Glew gravity corer with $7.62 \mathrm{~cm}$ internal diameter tube (Glew et al., 2001). Core lengths varied from $\sim 27-52 \mathrm{~cm}$ (Tab. 1) and were sectioned into $0.5-\mathrm{cm}$ intervals upon return to base camp. Core samples were shipped to Queen's University, Kingston, Ontario where they were stored in a $4^{\circ} \mathrm{C}$ cold room until further analysis. The weight of all sediment samples was determined to calculate the total weight of sediment prior to any sub-sampling.

\section{Radiometric dating and sample resolution}

Twenty-one intervals were prepared for ${ }^{210} \mathrm{~Pb}$ analysis and counted using gamma spectroscopy at the Paleoecological Environmental Assessment and Research Laboratory (PEARL) at Queen's University, Kingston, Ontario with samples closely spaced in the upper $10-\mathrm{cm}$ of sediment (every $1 \mathrm{~cm}$ ) and more coarsely spaced in deeper deposits (every $2 \mathrm{~cm}$ ) down to $30 \mathrm{~cm}$. Samples were freeze dried and the dry weight and percent moisture in each sample was determined. For gamma spectroscopy, dried sediment was weighed into a plastic tube, sealed with epoxy, and equilibrated for a minimum of 2 weeks to allow ${ }^{214} \mathrm{Bi}$ to equalize with ${ }^{226} \mathrm{Ra}$, the parent isotope of ${ }^{210} \mathrm{~Pb}$. Activities of ${ }^{210} \mathrm{~Pb},{ }^{137} \mathrm{Cs}$, and supported ${ }^{210} \mathrm{~Pb}$ (via ${ }^{214} \mathrm{~Pb}$ and ${ }^{214} \mathrm{Bi}$ ) were determined for each sample using an ORTEC well detector, as described in Schelske et al. (1994). Unsupported ${ }^{210} \mathrm{~Pb}$ activities were used to estimate the chronology of the cores using the constant rate of supply (CRS) model (Appleby and Oldfield, 1978) using the MATLAB programme ScienTissME (M. Scheer, unpublished data) with calibration to IAEA standards 312 \& 385 . Unsupported ${ }^{210} \mathrm{~Pb}$ was calculated by subtracting supported ${ }^{210} \mathrm{~Pb}$. Age-depth models were calculated in R version 3.1.2 (R Core Team, 2010) using a cubic spline with a monotonicity constraint.

Sediment samples from each core were dated prior to sampling for diatoms. The target sampling strategy focused on sediments deposited after ca. $1890 \mathrm{CE}$ and at a temporal resolution of $\sim 5$ years. Cores from Imp $\mathrm{N}$ lakes $10 \mathrm{Y}$ and $6 \mathrm{E}$ had to have additional samples prepared and counted based on unsupported ${ }^{210} \mathrm{~Pb}$ not being reached by $30 \mathrm{~cm}$.

\section{Diatom analyses}

For each analyzed sediment interval, $\sim 0.2-0.3 \mathrm{~g}$ of wet sediment was subsampled into a $20-\mathrm{mL}$ glass vial to which was added a 1:1 molar mixture of concentrated nitric $\left(\mathrm{HNO}_{3}\right)$ and sulphuric $\left(\mathrm{H}_{2} \mathrm{SO}_{4}\right)$ acid to remove organic matter. Samples settled $24 \mathrm{~h}$ before the acid above was aspirated and the residue rinsed to a constant $\mathrm{pH}$ with distilled water. Four aliquots of each sample were pipetted onto coverslips, and coverslips were air-dried overnight before heating on a warming plate and mounting with Naphrax $^{\circledR}$ onto glass microscope slides. Diatoms were identified and counted along transects on slides using a Leica (DMRB model) microscope fitted with a 100x fluotar objective (numerical aperture of objective $=1.3$ ) and using differential interference contrast optics at $1000 \mathrm{x}$ magnification. Approximately 400 diatom valves were enumerated per slide. Diatoms were identified to the species level or lower, using the following taxonomic references: Krammer and Lange-Bertalot (1986, 1988, 1991a, 1991b), Lange-Bertalot and Melzeltin (1996), Camburn and Charles (2000) and Fallu et al. (2000).

Sedimentary concentrations of diatoms in each sample were determined following Battarbee and Kneen (1982). Briefly, an aliquot of a known concentration of microspheres was added to each diatom sample, prior to subsampling for mounting on coverslips. The microspheres were enumerated along with the diatoms and used to calculate estimates of number of diatoms per gram dry weight of sediment. The flux rates of total planktonic diatoms and specific planktonic taxa groups were calculated by multiplying the concentration (\# valves per g dry weight) by the sedimentation rate $\left(\mathrm{g} \mathrm{cm}^{2} \mathrm{y}^{-1}\right)$ from the CRS chronology model.

\section{Numerical analyses}

The degree of species turnover in the diatom assemblages within each core since ca. $1900 \mathrm{CE}$ was assessed using two methods. The first method used the gradient length of a detrended correspondence analysis (DCA) (Smol et al., 2005) using Canoco 5 (Šmilauer and Lep, 2014). The second method compared the community similarity of each sample assemblage to that from sediments deposited ca. 1900 CE using the Bray-Curtis similarity coefficient on diatom taxa present at an abundance of both 2 and 5\% using Primer version 6.1.11 (Clark and Warwick, 2001). The ca. $1900 \mathrm{CE}$ samples in the cores ranged from an age of 1892 to 1910 (1922 for Lake 2L), with a mean age of $1902 \mathrm{CE}$.

\section{RESULTS}

\section{Lake characteristics}

All reference lakes (both $\mathrm{N}$ - and P-limited) are located within the Boreal Shield Ecozone (Tab. 1, Fig. 1). The majority of the impact lakes (N-and P-limited) are also located within the Boreal Shield Ecozone, with three lo- 
cated within the Boreal Plain Ecozone. The majority of the lakes have surface areas of between 20 to 90 ha, with 1 lake having surface area of $\sim 9$ ha and four that are larger at $\sim 130$ to 170 ha (Tab. 1). Most lakes are relatively shallow, with maximum depths of $\sim 5$ to $11 \mathrm{~m}$ and four slightly deeper at $\sim 15$ to $29 \mathrm{~m}$. Lakes are circumneutral (pH 6.87.3), with low DOC (range 1.8-7.1 $\mathrm{mg} \mathrm{L}^{-1}$ ), low alkalinity (4.2- $18.11 \mathrm{mg} \mathrm{L}^{-1}$ ) and low specific conductance (13.8$35.5 \mu \mathrm{S} \mathrm{cm}^{-1}$ ).

Phosphorus levels of the lakes were within the oligotrophic to mesotrophic range (Wetzel, 2001), with estimated mean TP of $\sim 3-18 \mu \mathrm{g} \mathrm{L}^{-1}$ (Tab. 1). The Ref and Imp P-limited lakes were within the oligotrophic range with mean TP of $\sim 3-8 \mu \mathrm{g} \mathrm{L}^{-1}$ and the Ref and Imp N-limited lakes were within the mesotrophic range with mean TP of $\sim 12-18 \mu \mathrm{g} \mathrm{L}^{-1}$. Mean Chl $a$ data from the P-limited lakes (both Ref and Imp) were within the oligotrophic range (Wetzel, 2001), with overall mean Chl $a$ of $2.1 \mathrm{mg} \mathrm{m}^{-3}$ (range 1.3-3.1) for the Imp P lakes and overall mean Chl $a$ of $2.4 \mathrm{mg} \mathrm{m}^{-3}$ (range 2.0-3.2) for the Ref P lakes (Tab. 1). Whereas the N-limited lakes (both Ref and Imp), fall with the mesotrophic range, with overall mean Chl $a$ of $5.2 \mathrm{mg}$ $\mathrm{m}^{-3}$ (range 4.4-6.2) for the Ref $\mathrm{N}$ lakes and mean of 6.0 $\mathrm{mg} \mathrm{m}^{-3}$ (range 3.9-7.3) for the Imp $\mathrm{N}$ lakes.

\section{Chronology and resolution}

The majority of cores in the study lakes showed an exponential decline in total ${ }^{210} \mathrm{~Pb}$ activity with sediment depth (Supplementary Fig. 1) enabling the development of strong depth-time chronologies. The coefficient of determination $\left(\mathrm{r}^{2}\right)$ ranged from $0.69-0.99$, with only 3 lakes with an $\mathrm{r}^{2}<0.8$ (lakes 2L, 10E, 10Y). Background (or supported) levels of ${ }^{210} \mathrm{~Pb}$ (total ${ }^{210} \mathrm{~Pb}$ activity equals total ${ }^{214} \mathrm{Bi}$ activity) were reached by $18-40 \mathrm{~cm}$ (median $=22 \mathrm{~cm}$ ) in the N-limited lakes (Ref and Imp), and by $5-20 \mathrm{~cm}$ (me$\operatorname{dian}=12 \mathrm{~cm}$ ) in the P-limited lakes (Ref and Imp). Sediment accumulation rates were generally much higher in the N-limited lakes. The relationship between log unsupported ${ }^{210} \mathrm{~Pb}$ and cumulative dry mass was generally strong $\left(\mathrm{r}^{2}=0.77-0.96\right)$. Although two lakes (Ref P- $2 \mathrm{~L}$ and Imp N-10E) had a weaker relationship between unsupported ${ }^{210} \mathrm{~Pb}$ and cumulative dry mass $\left(\mathrm{r}^{2}=0.53-0.56\right)$, the dating models are sufficient to access whether changes in species composition were concomitant with development of the Athabasca Oil Sands.

The number of samples analyzed since ca. $1890 \mathrm{CE}$ varied between the cores due to the varying sediment accumulation rates. The median number of post-1890 CE samples in the N-limited lakes was 25 (range 21-36) and 20 (range 9-25) in the P-limited lakes. The average resolution between samples for the majority of the lakes (12 of 15) ranged from $\sim 3$ to 6 years (median $=5 \mathrm{yrs}$ ), with slightly lower resolution in Imp P-13L, at an average resolution of 7 years between samples. Only two lakes, Ref
P-17F and Ref P-17P, were not analyzed at a sub-decadal resolution due to low sediment accumulation rates, with average resolution of $\sim 10$ and 14 years, respectively.

\section{Diatom species assemblages and similarity analyses}

An average of $\sim 160$ diatom taxa (range 94-269) were identified within each of the study lakes; however, the majority of these were rare, with only 13-55 (average 26) reaching $>2 \%$, and 7-22 taxa reaching abundances greater than $5 \%$. The planktonic component of the assemblages varied across the lakes from $\sim 3 \%$ in Ref N-2F to $87 \%$ in Imp P-11G (Fig. 2). There were few (if any) notable trends in the total \% of planktonic taxa (Fig. 2), total planktonic concentrations (Supplementary Fig. 2), total planktonic flux (Supplementary Fig. 3), or in the dominant benthic taxa (Supplementary Figs. 4 and 5), either within or between the four lake groups defined based on DIN:TP ratios and geographic position either inside or outside the depositional area. Total planktonic concentrations for each lake are highly related to the total planktonic flux $(\mathrm{r}=0.6-0.99)$, with the exceptions of lakes $2 \mathrm{Q}$, $2 \mathrm{~L}$ and $10 \mathrm{Y}(\mathrm{r}=0.2-0.44)$. A few lakes did record small variations in the taxonomic relative abundance of the dominant planktonic species in more recently deposited sediments (Fig. 3, Supplementary Figs. 4 and 5).

The predominant planktonic diatom taxa present in the cores varied between the lakes (Supplementary Figs. 4 and 5). A majority of the lakes (12 of 15) contained small centric Discostella (mostly D. stelligera (Cleve \& Grunow) Houk \& Klee and some D. pseudostelligera (Hustedt) Houk \& Klee), ranging from $\sim 2$ to $54 \%$ of the assemblage with only 5 lakes $>\sim 20 \%$ (Fig. 3A). Other Cyclotella (michiganiana Skvortzow, bodanica lemanica (Müller ex Schröter) Bachmann, tripartia Håkansson, ocellata Pantocsek) were typically present at lower percentages, except in Imp P-11G where C. tripartia comprised $\sim 20-40 \%$ of the assemblage and in Imp P-13L where C. ocellata was $\sim 10-20 \%$ (Supplementary Fig. $5 \mathrm{~d}$ ). Other planktonic taxa included representatives of the genus Aulacoseira (ambigua Simonsen, subarctica (Müller) Haworth, distans (Ehrenberg) Simonsen group, crenulata (Ehrenberg) Thwaites, tenella (Nygaard) Simonsen, perglabra (Øestrup) Haworth), although these species rarely reached $>20 \%$ of the assemblage, except in Ref N$17 \mathrm{~J}$ in which $A$. ambigua and $A$. subarctica when combined comprised $\sim 30-40 \%$ of assemblage (Supplementary Fig. 5a) and in Imp N-9C in which A. ambigua comprised $\sim 20-30 \%$ (Supplementary Fig. 5c). A number of lakes also contained pennate planktonic taxa (Asterionella formosa Hassall, Fragilaria tenera (Smith) Lange-Bertalot, Tabellaria flocculosa (Roth) Kützing strain 3p sensu Koppen), which typically comprised less than $\sim 10 \%$ of the assemblage, except the recent sediments in Imp N-10E which reached $>15 \%$ (Fig. 3B, Supplementary Fig. 5c). 
Fluctuations in the relative abundance of planktonic species were not consistent within or between the four lake groups in either direction or timing, but examples are noted, as comparable changes have often been related to recent climate change. The most notable Discostella increases of $\sim 10 \%$ were recorded after ca. $2000 \mathrm{CE}$ in Ref N-17V and Imp P-13N (Fig. 3A, Supplementary Fig. 5). Similar percent increases occurred in Imp N lakes 9C and 10 Y prior to ca. $2000 \mathrm{CE}$ (ca. 1980-2000 CE and ca.19301950 CE, respectively), while declines in Discostella were recorded in the Ref $\mathrm{P}$ lakes of variable timing (Fig. 3A, Supplementary Fig. 5). The most apparent increases in pennate planktonics occurred in Ref N-17J ( $A$. formosa and T. flocculosa str. 3p) and Imp N-10E (Fragilaria crotonensis Kitton and T. flocculosa str. 3p) lakes after ca. 2000 CE (Fig. 3B, Supplementary Fig. 5). Smaller relative increases in $A$. formosa were recorded in Imp N-6E (after ca. $2000 \mathrm{CE}$ ) and Imp P-10A (after ca. $1950 \mathrm{CE}$ ), with very small increases in $F$. tenera in Imp P-11G after ca.
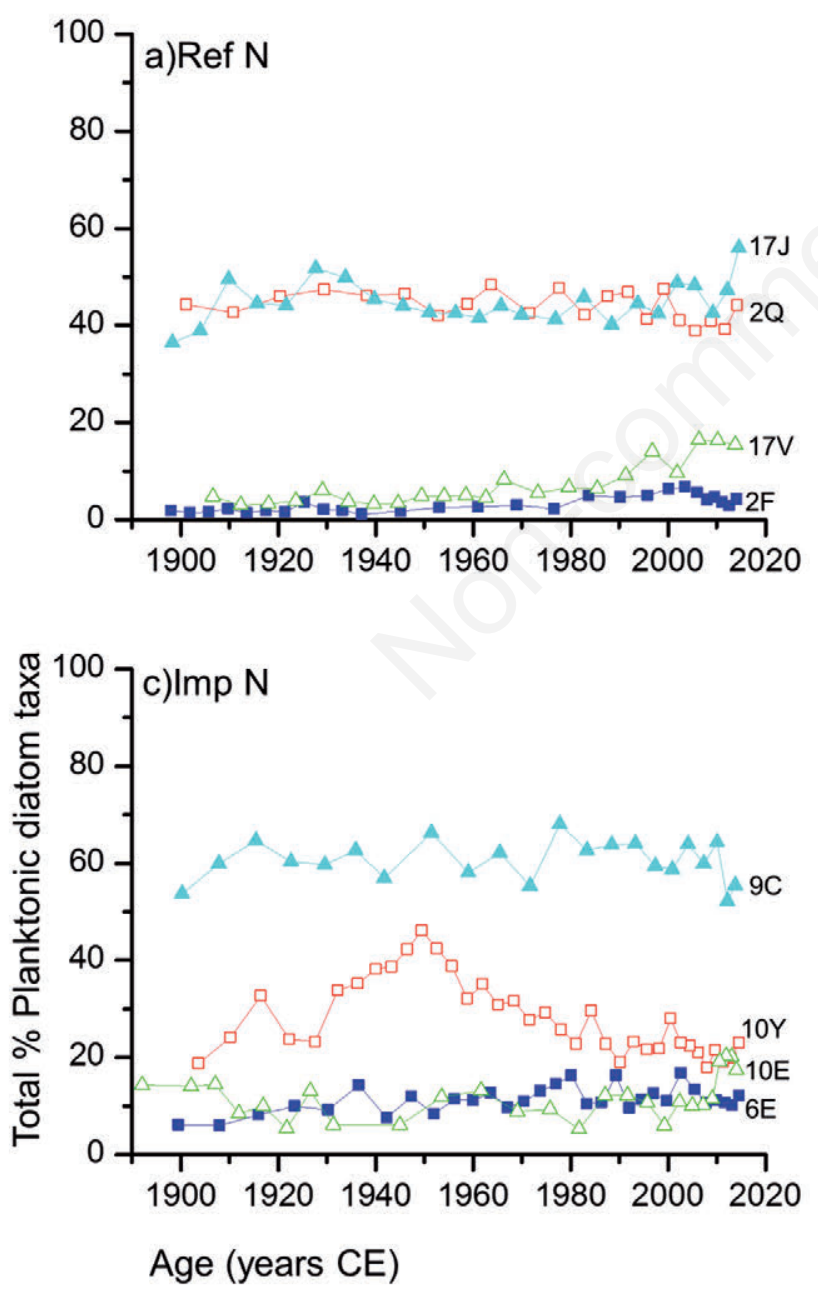

1970 CE. While declines in pennate planktonics occurred in Ref N-2Q following ca. 2000 and in Imp N-10Y after ca. 1980 CE. Planktonic Fragilaria (tenera, nanana Lange-Bertalot, capucina gracilis (Øestrup) Hustedt) comprised part of the Ref N-2Q assemblage and T. flocculosa str. $3 p$ and F. tenera in Imp N-10Y (Supplementary Fig. 5). Concentrations of the planktonic species groups generally followed the trends of the percent abundances (Supplementary Figs. 6 and 7) indicating that the changes in percent composition are generally representative of the fluctuations recorded in the core assemblages. Rates of flux of the planktonic species groups generally reflect the same patterns seen in the individual lake concentration data $(r=0.68-0.99$; Supplementary Figs. 8 and 9), with exception of lakes 2L, 2Q, $10 \mathrm{Y}$ and $17 \mathrm{~F}(\mathrm{r}=0.26-0.55)$.

Small Fragilariaceae Greville were the predominant benthic taxa in many of the lakes (Supplementary Figs. 3 and 4), reaching combined average abundances in each core from $\sim 5$ to $79 \%$. Staurosirella pinnata (Ehrenberg)
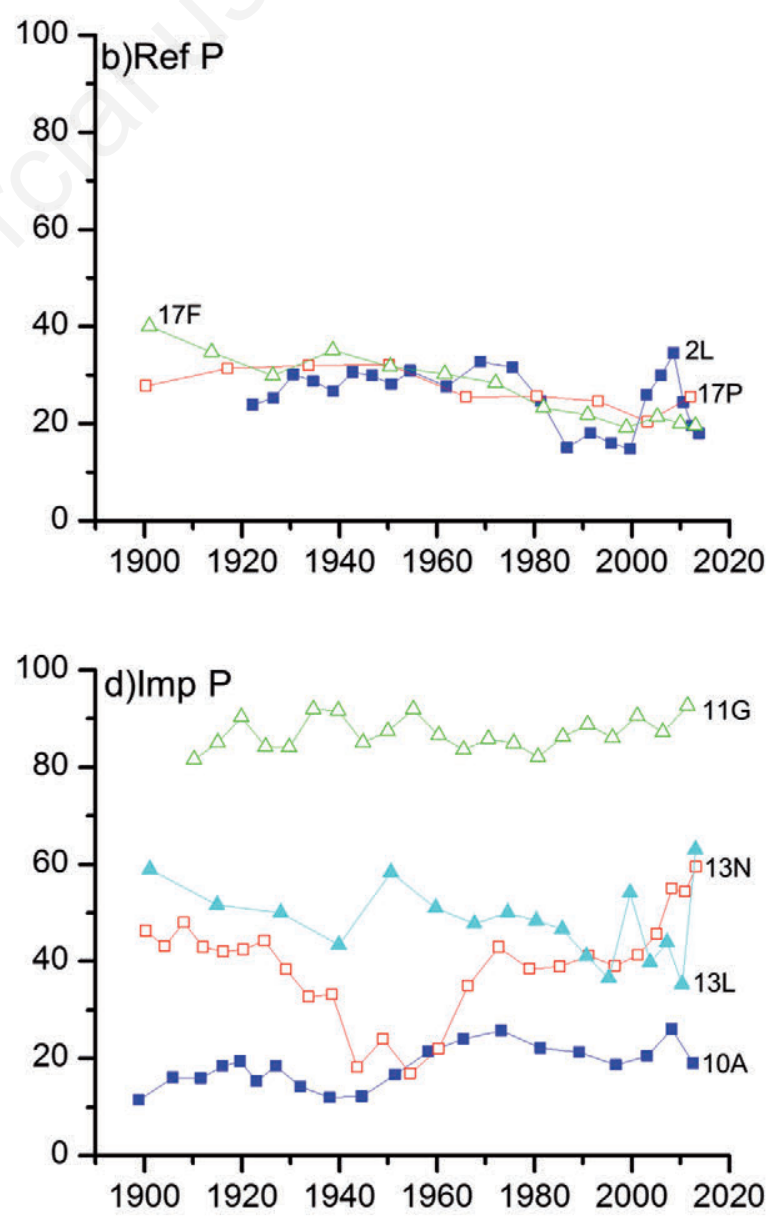

Fig. 2. Total percent planktonic diatom taxa for the a) Reference-N limited (Ref N) lakes, b) Reference P-limited (Ref P) lakes, c) Impact N-limited (Imp N) lakes and d) Impact P-limited (Imp P) lakes. 

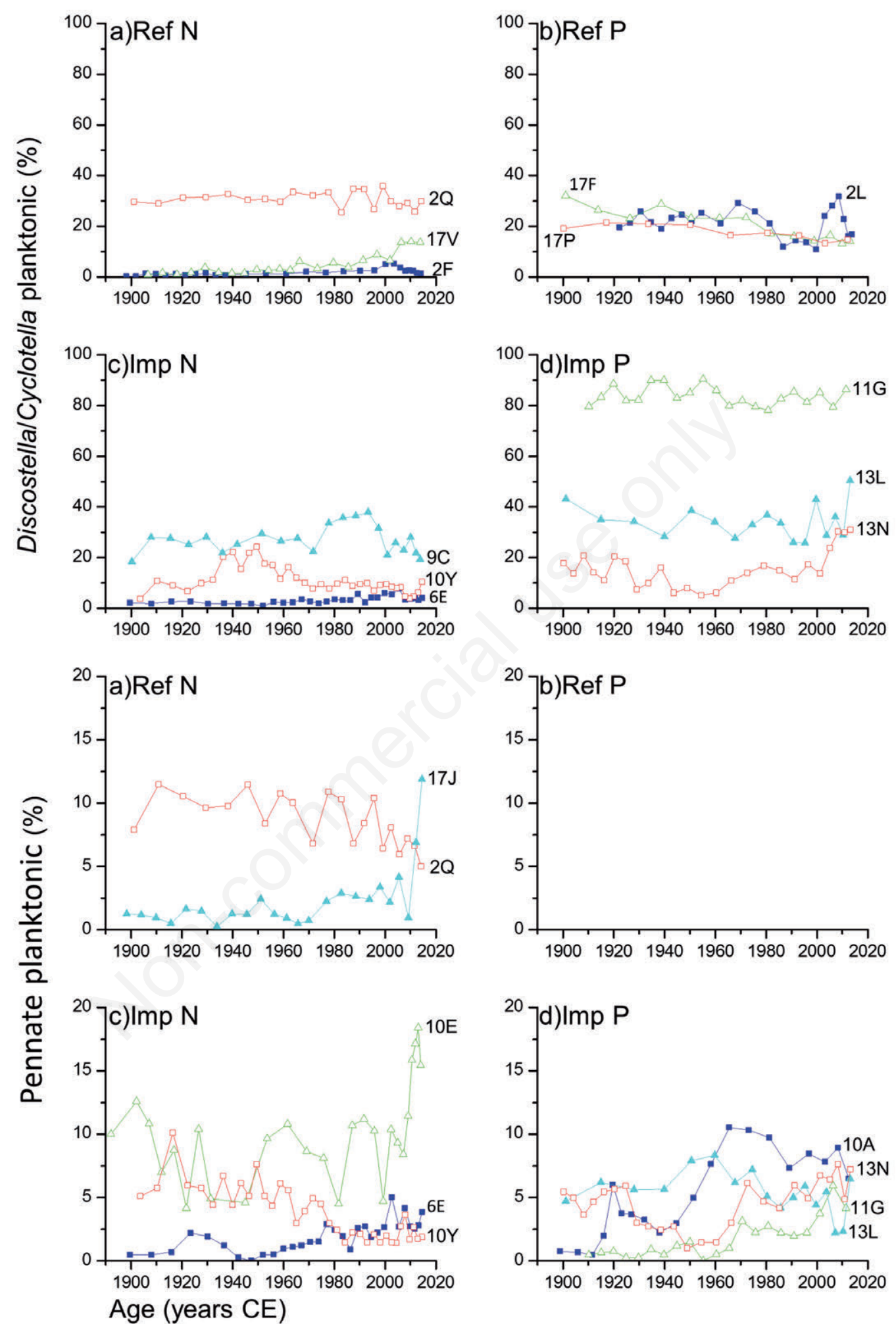

Fig. 3. A) Total percent small Discostella (mostly D. stelligera, with some D. pseudostelligera) and Cyclotella taxa (C. tripartita Lake $11 \mathrm{G}$ and $C$. ocellata Lake 13L) for the a) Reference-N limited (Ref N) lakes, b) Reference P-limited (Ref P) lakes, c) Impact N-limited $(\operatorname{Imp} N)$ lakes and d) Impact P-limited (Imp P) lakes. B). Total percent pennate planktonic taxa: Asterionella formosa, Fragilaria (F. crotonensis, F. tenera, F. nanana, F. capucina gracilis), Tabellaria flocculosa str. 3p for the a) Reference-N limited (Ref N) lakes, b) Reference P-limited (Ref P) lakes, c) Impact N-limited (Imp N) lakes and d) Impact P-limited (Imp P) lakes. There are no pennate planktonic taxa in Ref P lakes. 
Williams \& Round was often the most predominant small Fragilariaceae, with an average in each core ranging from $\sim 4$ to $74 \%$. Five of the lakes reached abundances $>50 \%$ of $S$. pinnata; all were N-limited lakes, two reference $(2 \mathrm{~F}$ and $17 \mathrm{~V})$ and three impact $(6 \mathrm{E}, 10 \mathrm{E}, 10 \mathrm{Y})$. There was no significant relationship between max depth of the lake and the percent abundance of the small Fragilariaceae $(r=-0.44, P=0.10)$, although there was a significant negative relationship of total benthic taxa and maximum depth $(\mathrm{r}=-0.62, \mathrm{P}=0.013)$. Benthic taxa comprised $>\sim 70 \%$ of the diatom assemblage in lakes $<10 \mathrm{~m}$ maximum depth, except for Ref N-17J which only achieved $\sim 40 \%$ benthic taxa.

Variability in the diatom species composition of the sediment assemblages was large across all lake groups, even with commonality of many taxa (Supplementary Figs. 4 and 5). Despite this pattern, there were few marked changes in diatom assemblages in individual lakes since ca. 1890
CE. Analysis of species turnover based on the DCA estimate was rarely greater than 1.0 (Supplementary Tab. 2) and, for most lakes, $20^{\text {th }}$ and $21^{\text {st }}$ century assemblage composition was highly similar ( $>80 \%)$ to that recorded in ca. $1900 \mathrm{CE}$ based on the analysis of species with either $2 \%$ (not shown) or 5\% relative abundance (Fig. 4). Only three lakes had any samples below 70\% similarity, Imp N-10Y and Imp P lakes 10A and 13N. Lake Imp N-10Y had a few samples below $70 \%$ similarity in the 1940 s as a result of a decrease in S. pinnata and an increase in Discostella (Supplementary Fig. 4). Lake Imp P-13N dropped to $\sim 55 \%$ similarity in the 1940s as the result of an increase in S. pinnata and other small Fragilariaceae, and a decrease in D. stelligera (Supplementary Fig. 4). Lake Imp P-10A had the lowest similarities of all lakes due to greater abundance of S. pinnata and Aulacoseira distans humilis in the early 1900s, later fluctuations in S. pinnata and increases in $A$. formosa after ca. 1950 CE (Fig. 4).
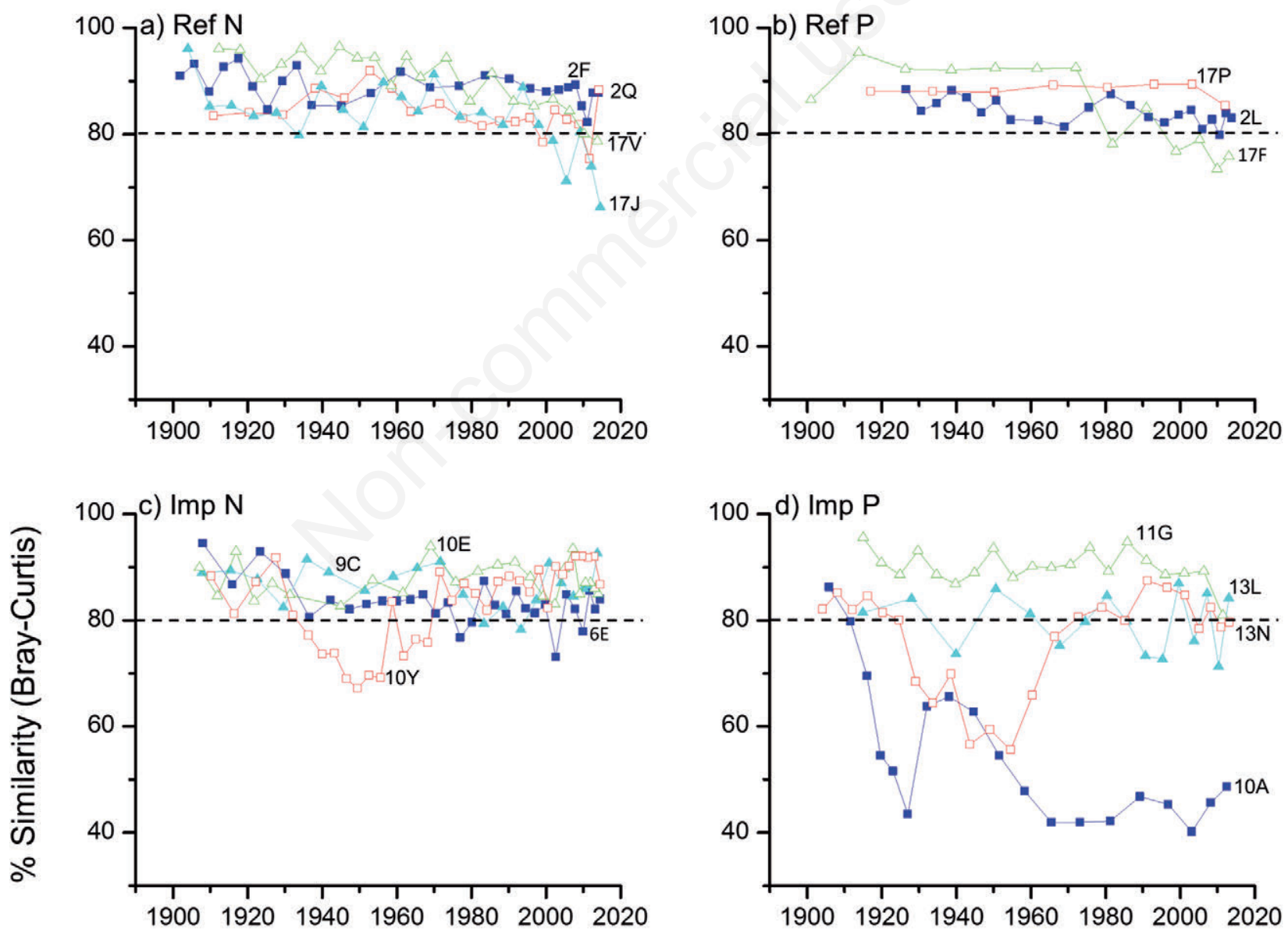

Age (years CE)

Fig. 4. Analysis of similarity by comparison of each sample to the c. 1900 sample using a Bray-Curtis coefficient on diatom taxa present at an abundance of 5\% for: a) Reference-N limited (Ref N) lakes; b) Reference P-limited (Ref P) lakes; c) Impact N-limited (Imp N) lakes; and d) Impact P-limited (Imp P) lakes. 


\section{DISCUSSION}

Analysis of our study lakes in a factorial design (AOSR-impacted, reference; $\mathrm{N}$ - and P-limited) revealed few effects of either industrial development or climatic warming on diatom assemblages in northwest Saskatchewan, Canada. Analysis of metrics of diatom community change (\% planktonic taxa, similarity analysis, species turnover) showed only minimal variation in assemblage composition in most study lakes (Figs. 2 and 4). The relative proportions and concentrations of many taxa were relatively stable over the past $\sim 125$ years (Fig. 3; Supplementary Figs. 4-7), other than generally small but nonsynchronous changes in centric taxa (Discostella and Cyclotella species) and pennate taxa, such as Asterionella formosa and Fragilaria crotonensis (Fig. 3), possibly reflecting individual lake response to climate. The absence of a consistent pattern of diatom changes associated with receipt of reactive nitrogen or intrinsic nutrient-limitation status of the lake suggests that AOSR emissions had no demonstrable effect on diatom composition.

\section{Lack of large changes in diatom assemblages}

Limited response of diatoms to the presumptive AOSR development may reflect the relatively low input of $\mathrm{Nr}$ to the boreal region of northwestern Saskatchewan. Distinct ecological response of diatoms to atmospheric deposition of industrially-derived $\mathrm{N}$ has been recorded in high-elevation alpine lakes in watersheds where limited terrestrial vegetation may favour $\mathrm{N}$ export directly to lakes (Wolfe et al., 2001; Saros et al., 2005b; Elser et al., 2009b; Baron et al., 2011). Estimated critical loads for diatom response in these Rocky Mountain basins range from $\sim 1$ to $3 \mathrm{~kg} \mathrm{~N} \mathrm{ha}^{-1} \mathrm{yr}^{-1}$ (Baron, 2006; Baron et al., 2011; Saros et al., 2011; Sheibley et al., 2014), whereas strong $\mathrm{N}$ effects in well vegetated eastern North American catchments have been estimated to require critical loads of $\sim 3.5-6 \mathrm{~kg} \mathrm{~N} \mathrm{ha}^{-1} \mathrm{yr}^{-1}$ (Baron et al., 2011). These higher critical loads to elicit a change in aquatic ecosystems within a well-forested basin may reflect local uptake and storage of industrial $\mathrm{N}$ by $\mathrm{N}$-limited catchment vegetation, as soil cover and vegetation composition has been found to influence $\mathrm{N}$ saturation and leaching (Baron et al., 2011; Lepori and Keck, 2012).

The forested boreal region of northwestern Saskatchewan exhibits higher land cover than alpine catchments, consequently atmospherically deposited $\mathrm{N}$ is more likely to be retained within the watershed (Environment Canada IMP, 2011b). In general, atmospheric nitrate and ammonium deposition from AOSR activities is greatest within $\sim 25-30 \mathrm{~km}$ of the industrial center (Laxton et al., 2012; Proemse et al., 2013; Watmough et al., 2014; Fenn et al., 2015). To date, $\mathrm{N}$ loads (together with sulfur,
S) have not caused widespread lakewater acidification due largely to mitigation by concomitant deposition of base cations (Watmough et al., 2014). Nitrogen cycling studies in Pinus banksiana and Populus tremuloides stands, suggests that soil $\mathrm{N}$ leaching was negligible for both types of forest plots, even within close proximity to the industrial center (Laxton et al., 2012). Vegetation throughfall data of DIN deposition was estimated at $2.1 \mathrm{~kg} \mathrm{ha}^{-1} \mathrm{yr}^{-1} \sim 25$ $\mathrm{km}$ from the industrial center, which decreased to $\sim 1.1 \mathrm{~kg}$ $\mathrm{ha}^{-1} \mathrm{yr}^{-1}$ at sites located 113 and $129 \mathrm{~km}$ away from the main source (Fenn et al., 2015). These distant loads are similar to critical loads found to enrich high-elevation lakes within watersheds that have limited vegetation, but may be insufficient to saturate terrestrial plant demand and favour N export to Saskatchewan lakes downwind from the AOSR.

Limited diatom response to AOSR emissions could be a reflection of benthic diatoms being an important component of many of the fossil assemblages in our study basins (Fig. 2, Supplementary Figs. 4 and 5). The majority of our study lakes were dominated by benthic diatom taxa, with lakes generally having a planktonic component of $<40 \%$, with only two lakes $>\sim 60 \%$ planktonic taxa (Imp N-9C and Imp P-11G). While littoral zones tend to be areas of high production and biodiversity, benthic algal production is often limited by light rather than nutrients, and may not respond as readily to nutrient fertilization (Vadeboncoeur et al., 2001; Cantonati and Lowe, 2014; Vadeboncoeur et al., 2014). The high complexity of benthic habitats and the close proximity of benthic algae to dissolved and particulate organic matter in the sediments has been suggested to be the main reason for this pattern (Saros et al., 2005a, 2005b; Bennion et al., 2001; Davidson and Jeppesen, 2013). Although epilithic algal communities have been noted to be influenced by water-column nutrient concentrations (King et al., 2000; DeNicola et al., 2004), estimates of total phosphorus from diatom assemblages dominated by benthic taxa have been found to have weaker responses to nutrient levels (Cumming et al., 2015).

Limited diatom response to $\mathrm{Nr}$ emissions may also be a reflection of inter-annual or seasonal changes in limiting nutrients (Morris and Lewis, 1988; Axler et al., 1994; Bergström et al., 2008; Kolzau et al., 2014; Dolman et al., 2016). For example, unproductive Swedish lakes in regions of higher deposition of $\mathrm{Nr}$ were pushed into $\mathrm{N}$ limitation only as the DIN pool declined over the summer season (Bergström et al., 2008). The degree and duration of lake stratification, as well as lake depth, can also influence the seasonal progression of limiting nutrients. Shallow lakes and those tending towards polymictic regimes can be limited by $\mathrm{N}$ (or light) in the summer months as a result of denitrification, and release of $\mathrm{P}$ from the sediments in summer (Kolzau et al., 2014; Dolman et al., 
2016). Whereas, in deeper dimictic or monomictic lakes, a seasonal shift from $\mathrm{P}$ to $\mathrm{N}$ limitation may be limited by the isolating effect of stratification and any release of $\mathrm{P}$ from the sediments being trapped in the hypolimnion (Kolzau et al., 2014). While our deeper lakes (max depths $\sim 15-29 \mathrm{~m}$ ) were generally P-limited, the majority of our study lakes have max depths ranging from $\sim 5-11 \mathrm{~m}$, and were either N- or P-limited (Tab. 1).

Muted response of diatoms to atmospherically deposited $\mathrm{Nr}$ has been recorded in previous studies. For example, Spaulding et al. (2015) recorded synchronous, but small increases ( $\sim 1-3 \%)$ of either A. formosa or F. crotonensis in relatively shallow (max depth $\sim 7-8.5 \mathrm{~m}$ ) alpine lakes, which were concurrent to estimates of $\mathrm{Nr}$ deposition from delta $\delta{ }^{15} \mathrm{~N}$ in the sediments. In contrast, the diatom assemblages in their shallowest lake (max depth $\sim 3.7 \mathrm{~m}$ ) did not show similar changes in diatom assemblages (Spaulding et al., 2015).

The planktonic taxa, A. formosa and F. crotonensis have been identified previously as indicators of anthropogenic $\mathrm{Nr}$ deposition in a number of alpine lakes (Wolfe et al., 2003; Saros et al., 2003, 2005b). Increases in A. formosa and other pennate planktonics have also been suggested to be related to changes in the thermal stability of lakes (Rühland et al., 2015), as well as being linked to early increases in anthropogenic lake eutrophication (Anderson et al., 1995). The generally small increases of these planktonic taxa in our study lakes, with exception of the larger rise in Ref N-17J and Imp N-10E, were asynchronous and occurred across the different lake groups, suggesting that $\mathrm{N}$ deposition did not drive these changes. Interestingly, increases generally occurred in the more mesotrophic lakes with smaller surface areas ( $\sim 9-41$ ha $v s$ $\sim 60-170 \mathrm{ha}$ ), thus nutrient status and physical aspects of the lakes cannot be discounted as factors influencing these changes.

\section{Is there a climate signal in the small phytoplankton changes?}

Atmospheric mean annual temperature has increased during the $20^{\text {th }}$ century by $\sim 2^{\circ} \mathrm{C}$ in both northern Alberta (Laird et al., 2013) and northern Saskatchewan, particularly after the mid-1970s (Adjusted and Homogenized Canadian Climate Data archive, http://ec.gc.ca/dcchaahccd). These warming trends are consistent with those observed in other regions such as the Canadian Prairies and the boreal transition zones to the south of the present study (Schindler and Donahue, 2006). Analysis of seasonal temperature records from boreal regions of northwest Ontario indicated that the largest increases occurred during the winter months (Parker et al., 2009), with the result that more winter precipitation is now falling as rain (Schindler and Donahue, 2006) leading to changes in the timing and magnitude of snow melt and stream discharge.
In principle, such changes in temperature and precipitation could alter lake production even without an increase in the deposition of $\mathrm{N}$.

Longer growing seasons and higher water-column temperatures may manifest as increases in phytoplankton production in boreal lakes (Karlsson et al., 2005; Bergström et al., 2013), whereas cold temperatures can constrain growth even when excess nutrients are available (Thompson et al., 2008; Bergström et al., 2013). In this study, we found little evidence for coherent changes in the timing, magnitude or direction of change in small centric taxa (Discostella, Cyclotella), where previous studies have linked recent increases to climate warming (Rühland et al., 2008, 2015). Several of our study lakes recorded increases in both percent abundance and concentrations of Discostella taxa (Ref N-17V, Imp N-9C and 10Y, Imp $\mathrm{P}-13 \mathrm{~L}$ and $13 \mathrm{~N}$ ), but timing of these changes were variable, and other lakes indicated declines in the relative abundance of this taxon (Ref P-17P and 2L). Rates of flux of Discostella were also variable within and between the lake groups. Similarly, there was no apparent pattern in which lakes indicated increases in Discostella in terms of morphological characteristics of lake surface area and maximum depth. While climate warming has affected surface-water temperatures and duration of stratification across the globe, these affects can be modulated by differences in lake morphometry, ice cover, geomorphic factors and variability in climate factors (O'Reilly et al., 2015; Kraemer et al., 2015). A global assessment of warming of lake-surface waters indicated a high degree of spatial heterogeneity with lake characteristics strongly mediating the response to climate effects, whereas previous regional-scale studies suggested a higher coherency (O'Reilly et al., 2015). While there is a stronger coherence of ice-out dates among lakes within a region (Magnuson et al., 2004), differences in lake morphometry and variation in timing of planktonic blooms can result in highly variable responses of phytoplankton communities (Boeff et al., 2016). Thus, while many lakes around the world have experienced increases in small Cyclotella taxa (including taxa now in Discostella), thought to be the related to climate warming manifested through increased strength or duration of stratification (Rühland et al., 2008, 2015), other studies have shown a lack of coherency of change within a region (Perren et al., 2009; Hobbs et al., 2010; Saros et al., 2011, 2012; Boeff et al., 2016). While such high variability in response makes it difficult to identify a common causal mechanism (Vogt et al., 2011), incorporation of phytoplankton autoecology with individual study lake processes can improve on the ability to decipher potential mechanisms.

Variability in the seasonal timing of diatom blooms and relation to stratification varies across lakes (Boeff $e t$ al., 2016; Wiltse et al., 2016). For example, the timing of 
higher populations of D. stelligera occurred in two Experimental Lake Area boreal lakes from early spring into early summer (Wiltse et al., 2016) and occurred during both un-stratified spring and summer stratified periods in three Maine lakes (Boeff et al., 2016). Boeff et al. (2016) found there was very little relationship between ice-out records and the relative abundance of $D$. stelligera, suggesting that direct links between the timing of ice out and potential duration of summer stratification may not always be a primary driver. Furthermore, Wiltse et al. (2016) suggest that increases in the abundance of Discostella may be the result of increased duration of spring mixing with earlier ice out. Whereas in other lakes, the degree of thermal stratification may be the main driver of Discostella abundances (Saros et al., 2016). Nonetheless, changes in light and nutrient availability may also alter a direct relationship between $D$. stelligera and thermal stratification (Saros and Anderson, 2015). Our deepest lakes ( $>18 \mathrm{~m}$ depth) indicated very little change in the percentage of Discostella/Cyclotella and increases were variable in magnitude and timing in the other shallower lakes (Ref $\mathrm{N}-17 \mathrm{~V}$, Imp N-6E, Imp P-13N). Variability in the timing of blooms and changes through time of this taxon suggests caution in indiscrimately identifying common direct or indirect linkages to climate.

Recent increases in other planktonic taxa may be the result of interactions of climate influences with other lake chemical and biological processes. For example, increases of $A$. formosa in Lake Windermere were suggested to be related to nutrient enrichment, warming and increased overwintering populations (Thackeray et al., 2008). Whereas, direct links to changes in thermal stability are often difficult, as A. formosa has been found to be in high concentrations during both un-stratified and stratified conditions (Wolfe et al., 2003; Boeffe et al., 2016).

\section{CONCLUSIONS}

Analysis of diatom assemblages in a robust factorial design demonstrated that potential nutrient enrichment as a result of nitrogen deposition has not greatly altered the abundance or species composition of diatoms in boreal lakes downwind from the AOSR. Changes in diatom assemblages were minimal across all groups of the study design. Similarly, although temperature has increased in this region and may have had small effects on the diatom assemblages through influences of water temperatures on phytoplankton growth, water column stability, or other direct or indirect effects or interactions, there was a lack of regional coherence in the direction and timing of most species change, including Discostella and small $C y$ clotella, which have been previously related to climate changes. Similarly, whereas five small, shallow $(<\sim 10 \mathrm{~m}$ depth and less than 40 ha area), and generally mesotrophic lakes exhibited recent increases in A. formosa or F. crotonensis, the specific factors which influenced these changes and the Discostella/Cyclotella changes are uncertain and require further study.

\section{ACKNOWLEDGMENTS}

We would like to thank Steve Wilke for assistance in the field and our pilot, Shane O'Neil from Star Helicopters. Funding was provided by Natural Sciences and Engineering Research Council of Canada (Grant No. STPGP1447139-2013), Environment Canada, and Saskatchewan Ministry of Environment.

\section{REFERENCES}

Aherne J, Shaw DP, 2010. Impact of sulphur and nitrogen deposition in western Canada. J. Limnol. 69(Suppl 1):1-3.

Anderson NJ, Renberg I, Segerström U, 1995. Diatom production responses to the development of early agriculture in a boreal forest lake-catchment (Kassjön, northern Sweden). J. Ecol. 83:809-822.

Appleby PG, Oldfield F, 1978. The calculation of lead-210 dates assuming a constant rate of sully of unsupported ${ }^{210} \mathrm{~Pb}$ to the sediment. Catena 5:1-8.

Axler RP, Rose C, Tikkanen CA, 1994. Phytoplankton nutrient deficiency as related to atmospheric nitrogen deposition in northern Minnesota acid-sensitive lakes. Can. J. Fish. Aquat. Sci. 51:1281-1296.

Baron JS, 2006. Hindcasting nitrogen deposition to determine an ecological critical load. Ecol. Appl. 16:433-439.

Baron JS, Driscoll CT, Stoddard JL, Richer EE, 2011. Empirical critical loads of atmospheric nitrogen deposition for nutrient enrichment and acidification of sensitive US lakes. BioScience 61:602-613.

Battarbee RW, Kneen MJ, 1982. The use of electronically counted microspheres in absolute diatom analysis. Limnol. Oceanogr. 27:184-188.

Bennion H, Appleby PG, Phillips GL, 2001. Reconstructing nutrient histories in the Norfolk Broads, UK: implications for the role of diatom-total phosphorus transfer functions in shallow lake management. J. Paleolimnol. 26:181-204.

Bergström A, 2010. The use of TN:TP and DIN:TP ratios as indicators for phytoplankton nutrient limitation in oligotrophic lakes affected by N deposition. Aquat. Sci. 72:277.281.

Bergström A, Faithfull, Karlsson D, Karlsson J, 2013. Nitrogen deposition and warming - effects on phytoplankton nutrient limitation in subarctic lakes. Global Change Biol. 19:25572568 .

Bergström A, Jansson M, 2006. Atmospheric nitrogen deposition has caused nitrogen enrichment and eutrophication of lakes in the northern hemisphere. Global Change Biol. 12:635-643.

Bergström A, Jonsson A, Jansson M, 2008. Phytoplankton responses to nitrogen and phosphorus enrichment in unproductive Swedish lakes along a gradient of atmospheric nitrogen deposition. Aquat. Biol. 4:55-64.

Boeff KA, Strock KE, Saros JE, 2016. Evaluating planktonic di- 
atom response to climate change across three lakes with differing morphometry. J. Paleolimnol. 56:33-47.

Camburn KR, Charles DF, 2000. Diatoms of low-alkalinity lakes in the Northeastern United States. Academy of Natural Sciences, Philadelphia.

Cantonati M, Lowe RL, 2014. Lake benthic algae: toward an understanding of their ecology. Freshwater Science 33:475-486.

Clark KR, Warwick RM, 2001. Change in marine communities: an approach to statistical analysis and interpretation. second edition. Primer-E, Plymouth.

Cumming BF, Davey KA, Smol JP, Birks HJB, 1994. When did acid-sensitive Adirondack lakes (New York, USA) begin to acidify and are they still acidifying? Can. J. Fish. Aquat. Sci. 51:1550-1568.

Cumming BF, Laird KR, Gregory-Eaves I, Simpson KG, Sokal MA, Nordin RN, Walker IR, 2015. Tracking past changes in lake-water phosphorus with a 251-lake calibration dataset in British Columbia: tool development and application in a multiproxy assessment of eutrophication and recovery in Osoyoos Lake, a transboundary lake in Western North America. Front. Ecol. Evol. 3:84.

Curtis CJ, Flower R, Rose N, Shilland J, Simpson GL, Turner S, Yang H, Pla S, 2010. Palaeolimnological assessment of lake acidification and environmental change in the Athabasca Oil Sands Region, Alberta. J. Limnol. 69(Suppl. 1):92-104.

Davidson TA, Jeppesen E, 2013. The role of palaeolimnology in assessing eutrophication and its impact on lakes. J. Paleolimnol. 49:391-410.

DeNicola DM, deEyto E, Wemaere A, Irvine K, 2004. Using epilithic algal communities to assess trophic status in Irish lakes. J. Phycol. 40:481-495.

Dolman AM, Mischke U, Wiedner C, 2016. Lake-type-specific seasonal patterns of nutrient limitation in German lakes, with target nitrogen and phosphorus concentrations for good ecological status. Freshwater Biol. 61:444-456.

Downing JA, McCauley E, 1992. The nitrogen: phosphorus relationship in lakes. Limnol. Oceanogr. 37: 936-945.

Elser JJ, Andersen T, Baron JS, Bergström A, Jansson M, Kyle M, Nydick KR, Steger L, Hessen DO, 2009a. Shifts in lake $\mathrm{N}: \mathrm{P}$ stoichiometry and nutrient limitation driven by atmospheric nitrogen deposition. Science 326:835-837.

Elser JJ, Kyle M, Steger L, Nydick KR, Baron JS, 2009b. Nutrient availability and phytoplankton nutrient limitation across a gradient of atmospheric nitrogen deposition. Ecology 90:3062-3073.

Elser JJ, Marzolf ER, Goldman CR, 1990. Phosphorus and nitrogen limitation of phytoplankton growth in the freshwaters of North America: A review and critique of experiments enrichments. Can. J. Fish. Aquat. Sci. 47:1468-1477.

Environment Canada IMP, 2011a. Integrated Monitoring Plan for the Oil Sands: Air quality component. Available from: https://www.ec.gc.ca/pollution/default.asp?lang=En\&n= EACB8951-1.

Environment Canada IMP, 2011b. Integrated monitoring plan for the Oil Sands: Expanded geographic extent for water quality and quantity, aquatic biodiversity and effects, and acid sensitive lake component. Available from: https:/Www.ec.gc. ca/pollution/default.asp?1 ang=En\&n=EACB8951-1

Fallu M, Allaire N, Pienitz R, 2000. Freshwater diatoms from
Northern Quebec and Labrador (Canada). Bibliotheca Diatomologica Band 45. Gebrueder Borntraeger, Berlin.

Fenn ME, Baron JS, Allen EB, Rueth HM, Nydick KR, Geiser L, Bowman WD, Sickman WD, Meixner T, Johnson DW, Neitlich P, 2003. Ecological effects of nitrogen deposition in the western United States. Bioscience 53:404-420.

Fenn ME, Bytnerowicz A, Schilling SL, Ross CS, 2015. Atmospheric deposition of nitrogen, sulfur and base cations in jack pine stands in the Athabasca Oil Sands Region, Alberta, Canada. Environ. Pollut. 196:497-510.

Glew JR, Smol JP, Last WM, 2001. Sediment core collection and extrusion, p. 73-105. In W.M. Last and J.P. Smol (eds.), Tracking environmental change using lake sediments. 1. Basin analysis, coring, and chronological techniques. Kluwer, Dordrecht.

Guildford SJ, Hecky RE, 2000. Total nitrogen, total phosphorus, and nutrient limitation in lakes and oceans: Is there a common relationship? Limnol. Oceanogr. 45:1213-1223.

Hazewinkel RRO, Wolfe AP, Pla S, Curtis C, Hadley K, 2008. Have atmospheric emissions from the Athabasca oil sands impacted lakes in northeastern Alberta, Canada? Can. J. Fish. Aquat. Sci. 65:1554-1567.

Hobbs WO, Telford RJ, Birks JB, Saros JE, Hazewinkel RRO, Perren BB, Saulnier-Talbot E, Wolfe AP, 2010. Quantifying recent ecological changes in remote lakes of North America and Greenland using sediment diatom assemblages. PLoS One 5:e10026.

Karlsson J, Jonsson A, Jansson M, 2005. Productivity of highaltitude lakes: climate effect inferred from altitude gradient. Global Change Bio. 11:710-715.

Kelly EN, Schindler DW, Hodson PV, Short JW, Radmanovich R, Nielsen CC, 2010. Oil sands developmentcontributes elements toxic at low concentrations to the Athabasca River and its tributaries. P. Natl. Acad. Sci. USA 107:16178-16183.

King L, Barker P, Jones RI, 2000. Epilithic algal communities and their relationship to environmental variables in lakes of the English Lake District. Freshwater Biol. 45:425-442.

Kolzau S, Wiedner C, Rücker J, Köhler, Köhler A, Dolman A, 2014. Seasonal patterns of nitrogen and phosphorus limitation in four German lakes and the predictability of limitation status from ambient nutrient concentrations. PLoS One 9:e96065.

Kraemer BM, Anneville O, Chandra S, Dix M, Kuusisto E, Livingstone DM, Rimmer A, Schladow SG, Silow E, Sitoki LM, Tamatamah R, Vadeboncoeur Y, McIntyre PB, 2015. Morphometry and average temperature affect lake stratification responses to climate change. Geophys. Res. Lett. 42:4981-4988.

Krammer K, Lange-Bertalot H, 1986. [Bacillariophyceae. Teil 1. Naviculaceae]. In: H. Ettl, G. Gärtner, J. Gerloff, H. Heynig and D. Mollenhauer (eds.), [Süßwasserflora von Mitteleuropa, Band 2/1]. Gustav Fischer Verlag, Stuttgart.

Krammer K, Lange-Bertalot H, 1988. [Bacillariophyceae. 2. Teil: Bacillariaceae, Epithmiaceae, Surirellaceae]. In: H. Ettl, G. Gärtner, J. Gerloff, H. Heynig and D. Mollenhauer (eds.), [Süßwasserflora von Mitteleuropa, Band 2/2].[Book in German]. Gustav Fischer Verlag, Stuttgart/New York.

Krammer K, Lange-Bertalot H, 1991a. [Bacillariophyceae. 3. Teil: Centrales, Fragilariaceae, Eunotiaceae]. In: H. Ettl, G. Gärtner, J. Gerloff, H. Heynig and D. Mollenhauer (eds.), 
[Süßwasserflora von Mitteleuropa, Band 2/3].[Book in German]. Gustav Fischer Verlag, Stuttgart/Jena.

Krammer K, Lange-Bertalot H, 1991b. [Bacillariophyceae. 4. Teil: Achnanthaceae]. In: H. Ettl, G. Gärtner, J. Gerloff, H. Heynig and D. Mollenhauer (eds.), [Süßwasserflora von Mitteleuropa, Band 2/4].[Book in German]. Gustav Fischer Verlag, Stuttgart/Jena.

Kurek J, Kirk JL, Muir DCG, Wang X, Evans MS, Smol JP, 2013. The legacy of a half century of Athabasca oil sands development recorded by lake ecosytems. P. Natl. Acad. Sci. USA 110:1761-1766.

Laird KR, Bas B, Kingsbury M, Moos MT, Pla-Rabes S, Ahad JME, Wiltse B, Cumming BF, 2013. Paleolimnological assessment of limnological change in 10 lakes from northwest Saskatchewan downwind of the Athabasca oils sands based on analysis of siliceous algae and trace metals in sediment cores. Hydrobiologia 720:55-73.

Lange-Bertalot H, Melzeltin D, 1996. Indicators of oligotrophy. 2 Iconographia Diatomologica. Koeltz Scientific Books, Königstein.

Laxton DL, Watmough SA, Aherne J, 2012. Nitrogen cycling in Pinus banksiana and Populus tremuloides stands in the Athabasca Oil Sands Region, Alberta, Canada. Water Air Soil Pollut. 223:1-13.

Lewis WM, Wurtsbaugh WA, 2008. Control of lacustrine phytoplankton by nutrients: Erosion of the phosphorus paradigm. Internat. Rev. Hydrobiol. 93:446-465.

Lepori F, Keck F, 2012. Effects of atmospheric nitrogen deposition on remote freshwater ecosystems. Ambio 41:235-246.

Lynam MM, Dvonch JT, Barres JA, Morishita M, Legge A, Percy K, 2015. Oil sands development and its impact on atmospheric wet deposition of air pollutants to the Athabasca Oil Sands Region, Alberta, Canada. Environ. Pollut. 206:469-478.

Magnuson JJ, Benson BJ, Kratz TK, 2004. Patterns of coherent dynamics within and between lake districts at local to intercontinental scales. Boreal Environ. Res. 93:446-465.

Morris DP, Lewis WM, 1988. Phytoplankton nutrient limitation in Colorado mountain lakes. Freshwater Biol. 20:315-327.

Nydick KR, Lafrancois BM, Baron JS, Johnson BM, 2004. Nitrogen regulation of algal biomass, productivity, and composition in shallow mountain lakes, Snowy Range, Wyoming, USA. Can. J. Fish. Aquat. Sci. 61:1256-1268.

O'Reilly CM, Sharma S, Gray DK, Hampton SE, Reads JS, Rowley RJ, Schneider P, Lenters JD, McIntyre PB, Kraemer BM, Weyhenmeyer GA, Straile D, Dong B, Adrian R, Allan MG, Anneville O, Arvola L, Austin J, Bailey JL, Baron JS, Brookes JD, de Eyto E, Dokulil MT, Hamilton DP, Havens K, Hetherington AL, Higgins SN, Hook S, Izmest'eva LR, Joehnk KD, Kangur K, Kasprzak P, Kumagai M, Kuusisto E, Leshkevich G, Livingstone DM, MacIntyre S, May L, Melack JM, Mueller-Navarra DC, Naumenko M, Noges P, Noges T, North RP, Plisnier P-D, Rigosi A, Rimmer A, Rogora M, Rudstam LG, Rusak JA, Salmaso N, Samal NR, Schindler DE, Schladow SG, Schmid M, Schmidt SR, Silow E, Soylu ME, Teubner K, Verburg P, Voutilainen A, Watkinson A, Williamson CE, Zhang G, 2015. Rapid and highly variable warming of lake surface waters around the globe. Geophys. Res. Lett. 42:10773-10781.

Parker BR, Schindler DW, Beaty KG, Stainton MP, Kasian
SEM, 2009. Long-term changes in climate, streamflow, and nutrient budgets for first-order catchments at the Experimental Lakes Area (Ontario, Canada). Can. J. Fish. Aquat. Sci. 66:1848-1863.

Perren BB, Douglas MSV, Anderson NJ, 2009. Diatoms reveal complex spatial and temporal patterns of recent limnological change in West Greenland. J. Paleolimnol. 42:233-247.

Proemse BC, Mayer B, Fenn ME, Ross CS, 2013. A multi-isotope approach for estimating industrial contributions to atmospheric nitrogen deposition in the Athabasca oil sands region in Alberta, Canada. Environ. Pollut. 182:80-91.

R Core Team, 2010. R: a language and environment for statistical computing. Vienna, Austria: R Foundation for statistical computing. Available from: http://www.R-project.org/

Rühland K, Paterson AM, Smol JP, 2008. Hemisphericscale patterns of climate-related shifts in planktonic diatoms from North American and European lakes. Global Change Biol. 14:2740-2754.

Rühland K, Paterson AM, Smol JP, 2015. Lake diatom responses to warming: reviewing the evidence. J. Paleolimnol. 54:1-35.

Saros JE, Anderson NJ, 2015. The ecology of the planktonic diatom Cyclotella and its implications for global environmental change studies. Biol. Rev. 90:522-541.

Saros JE, Clow DW, Blett T, Wolfe AP, 2011. Critical nitrogen deposition loads in high-elevation lakes of the western US inferred from paleolimnological records. Water Air Soil Pollut. 216:193-202.

Saros JE, Interlandi SJ, Doyle S, Michel TJ, Williamson CE, 2005a. Are the deep chlorophyll maxima in alpine lakes primarily induced by nutrient availability, not UV avoidance? Arctic Antarct. Alpine Res. 37:557-563.

Saros JE, Interlandi SJ, Wolfe AP, Engstrom DR, 2003. Recent changes in the diatom community structure of lakes in the Beartooth Mountain Range, U.S.A. Arctic Antarct. Alpine Res. 35:18-3.

Saros JE, Michel TJ, Interlandi SJ, Wolfe AP, 2005b. Resource requirements of Asterionella formosa and Fragilaria crotonensis in oligotrophic alpine lakes: implications for recent phytoplankton community reorganizations. Can. J. Fish. Aquat. Sci. 62:1681-1689.

Saros JE, Northington RM, Anderson DS, Anderson NJ, 2016. A whole-lake experiment confirms a small centric diatom species as an indicator of changing lake thermal structure. Limnol. Oceanogr. Letters doi: 10.1002/lol2.10024

Saros JE, Stone JR, Pederson GT, Slemmons EH, Spanbauer T, Schliep A, Cahl D, Willaimson CE, Engstrom DR, 2012. Climate-induced changes in lake ecosystem structure inferred from coupled neo- and paleoecological approaches. Ecology 93:2155-2164.

Schelske CL, Peplow A, Brenner M, Spencer CN, 1994. Lowbackground gamma counting: applications for ${ }^{210} \mathrm{~Pb}$ dating of sediments. J. Paleolimnol. 10:115-128.

Schindler DW, 2010. Tar sands need solid science. Nature 468:499-501.

Schindler DW, 2012. The dilemma of controlling cultural eutrophication of lakes. P. R. Soc. B 279:4322-4333.

Schindler DW, 2013. Geoscience of climate and energy 12. Water quality issues in the Oil Sands Region of the Lower Athabasca River, Alberta. Geoscience Canada 40:202-214.

Schindler DW, Donahue WF, 2006. An impending water crisis 
in Canada's western prairie provinces. P. Nat. Acad. Sci. USA 103:7210-7216.

Schindler DW, Carpenter SR, Chapra SC, Hecky RE, Orihel DM, 2016. Reducing phosphorus to curb lake eutrophication is a success. Environ. Sci. Technol. 50:8923-8929.

Scott KA, Wissel B, Gibson JJ, Birks SJ, 2010. Chemical characteristics and acid sensitivity of boreal headwater lakes in northwest Saskatchewan. J. Limnol. 69(Suppl 1):33-44.

Sheibley RW, Enache M, Swarzenski PW, Moran PW, Foreman JR, 2014. Nitrogen deposition effects on diatom communities in lakes from three national parks in Washington State. Water Air Soil Pollut. 225:1857.

Šmilauer P, Lep J, 2014. Multivariate Analysis of Ecological Data using CANOCO 5, 2nd ed. Cambridge University Press: $376 \mathrm{pp}$.

Smol JP, Battarbee RW, Davis RB, Merilainen J, 1986. Diatoms and lake acidity: reconstructing $\mathrm{pH}$ from siliceous algal remains in lake sediments. W. Junk, Dordrecht: 307 pp.

Smol JP, Wolfe AP, Birks HJB, Douglas MSV, Jones VJ, 2005. Climate-driven regime shifts in the biological communities of arctic lakes. P. Natl. Acad. Sci. USA 2:4397-4402.

Spaulding SA, Otu MK, Wolfe AP, Baron JS, 2015. Paleolimnological records of nitrogen deposition in shallow, high-elevation lakes of Grand Teton National Park, Wyoming, U.S.A. Arctic Antarct. Alpine Res. 47:703-717.

Sullivan TJ, Charles DF, Smol JP, Cumming BF, Selle AR, Thomas DR, Berneip JA, Dixit SS, 1990. Quantification of changes in lakewater chemistry in response to acidic deposition. Nature 345: 54-58.

Thackeray SJ, Jones ID, Maberly SC, 2008. Long-term change in the phenology of spring phytoplankton: species-specific responses to nutrient enrichment and climatic change. J. Ecol. 96:523-535.

Thompson PL, St. Jacques M, Vinebrooke RD, 2008. Impacts of climate warming and nitrogen deposition on Alpine plankton in lake and pond habitats: an in vitro experiment. Arctic Antarct. Alpine Res. 40:192-198.

Vadeboncoeur Y, Devlin SP, McIntyre PB, Zanden MJV, 2014. Is there light after depth? Distribution of periphyton chlorophyll and productivity in lake littoral zones. Freshwater Science 33:524-536.

Vadeboncoeur Y, Lodge DM, Carpenter SR, 2001. Whole-lake fertilization effects on distribution of primary production between benthic and pelagic habitats. Ecology 82:1065-1077.

Vogt RJ, Rusak JA, Patoine A, Leavitt PR, 2011.Differential effects of energy and mass influx on the landscape synchrony of lake ecosystems. Ecology 92:1104-1114.

Watmough SA, Whitfield CJ, Fenn ME, 2014. The importance of atmospheric base cation deposition for preventing soil acidification in the Athabasca Oil Sands Region of Canada. Sci. Total Environ. 493:1-11.

Wetzel RG, 2001. Limnology, lakes and rivers ecosystems, third edition. Academic Press, San Diego: 1006 pp.

Wiltse B, Paterson AM, Findlay DL, Cumming BF, 2016. Seasonal and decadal patterns in Discostella (Bacillariophyceae) species from bi-weekly records of two boreal lakes (Experimental Lakes Area, Ontario, Canada). J. Phycol. 52:817-826.

Winter TC, Likens GE, 2009. Mirror lake: Interactions among air, land, and water. University of California Press: 359 pp.

Wolfe AP, Baron JS, Cornett RJ, 2001. Anthropogenic nitrogen deposition induces rapid ecological changes in alpine lakes of the Colorado Front Range (USA). J. Paleolimnol. 25:1-7.

Wolfe AP, Gorp ACV, Baron JS, 2003. Recent ecological and biogeochemical changes in alpine lakes of Rocky Mountain National Park (Colorado, USA): a response to anthropogenic nitrogen deposition. Geobiology 1:153-168. 